九州大学学術情報リポジトリ

Kyushu University Institutional Repository

\title{
Effect of Temperature on Solubility of Wheat Gluten Heat Treated under Stress Pressure
}

Fujio, Yusaku

Laboratory of Food Processing, Faculty of Agriculture, Kyushu University

Lim, Jae-Kag

Laboratory of Food Processing, Faculty of Agriculture, Kyushu University

Hayakawa, Isao

Laboratory of Food Processing, Faculty of Agriculture, Kyushu University

https://doi.org/10.5109/23875

出版情報 : 九州大学大学院農学研究院紀要. 32 (3/4)，pp.157-164，1988-03. Kyushu University バージョン：

権利関係 : 


\title{
E ffect of Temperature on Solubility of W heat Gluten $H$ eat Treated under Stress Pressure
}

\author{
Yusaku Fujio, Jae-Kag Lim and Isao Hayakawa \\ Laboratory of Food Processing, Faculty of Agriculture, \\ Kyushu University 46-09, Fukuoka 812
}

(Received September 4. 1987)

\begin{abstract}
By using a Flow Tester, heat treated wheat gluten under stress pressure (by vertical load) and/or shearing force were investigated in terms of solubility in various solvents. Regarding the dependency of solubility on the heat treating temperature under the desired heating time and stress pressure, the solubility of gluten treated at $140^{\circ} \mathrm{C}$ was the lowest for each solvent tested. While the solubility of wheat gluten significantly increased with the increasing temperature above $140^{\circ} \mathrm{C}$, the solubility markedly decreased with increasing temperature at the temperature below $120^{\circ} \mathrm{C}$. Based on the heat treated gluten samples at $200^{\circ} \mathrm{C}$ for 5 minutes and $160^{\circ} \mathrm{C}$ for 60 minutes, it was evident that the $\mathrm{pH}$ of solvent also significantly affected the solubility for all solvents used. It appeared that stress pressure and shear force did not have any effect on the solubility of heat treated gluten. Within the scope of present work, it can be concluded that the solubility of heat treated gluten is dependent primarily on the treating temperature and the $\mathrm{pH}$ of solvent.
\end{abstract}

\section{INTRODUCTION}

As an attractive new technology for processing foods, the extrusion processing has become a major interest in the recent years. Especially, the texturization of protein rich materials by the extrusion processing has attracted the attention of many researchers, because inexpensive food materials which contain protein can be converted to more valuable food materials. In the case of extrusion processing, raw materials is processed in the extruder's barrel under a high temperature (up to $200^{\circ} \mathrm{C}$ ) and high shear force imparted by mechanical means. However, the physico-chemical changes of the subject material which take place in the barrel is still unknown since it is difficult to analyze the situation inside the barrel. Although there are some informations available on the changes and/or interactions between food ingredients during extrusion processing, parameters for extrusion should be individually studied. Sheard et al. (1986) have reported on macromolecular changes associated with the heat treatment of soya isolate (vegitable protein). Saio et al. $(1974,1975)$ have investigated the expansion characteristics and qualitative changes in protein during heating at $100-170^{\circ} \mathrm{C}$.

In this report, wheat gluten, which is a food ingredient, was treated under various conditions, i. e., various combinations of high temperature and high stress pressure imparted by a vertical load and/or shear force imparted by an orifice. Characteristics of the treated wheat gluten was analyzed in the terms of solubility, and it was revealed that the treating temperature and the $\mathrm{pH}$ of solvent significantly affected the solubility of the heat treated wheat gluten. 


\section{MATERIALS AND METHODS}

\section{Wheat gluten}

Vital wheat gluten was kindly donated by Nissin Seifun Co. Ltd. The wheat gluten was composed $8.2 \%$ of moisture, $70.7 \%$ of crude protein (as Kjeldahl nitrogen X 5.7) and $2.8 \%$ of ether extractable lipid.

Preparation of test sample

Moisture content of wheat gluten was adjusted to a desired level by adding the calculated amount of fine ice powder ground at $-20^{\circ} \mathrm{C}$ on to the wheat gluten. After mixing it thoroughly by a mixer (National Electric Co. Ltd., Cook Master, Model MK $-6000)$, the mixture was put in a polyethylene bag, and stood it for 3 days at $4^{\circ} \mathrm{C}$ for obtaining uniform moisture distribution. By this moisture adjustment method, wheat gluten samples with moisture content at 11, 23, 30, 39 and $49 \%$ were prepared for this work.

\section{Flow Tester}

Koka Flow Tester (Shimadzu Seisakusho Co. Ltd., Model No. 61323) was used in the heat treatment of wheat gluten sample under stress pressure. Fig. 1 shows the cross-sectional view of the Flow Tester Cell equipped with the temperature control system. Temperature of the sample holder in the Cell is controlled by an electric heater and cooling water. Size of the sample holder of the Cell is $11.3 \mathrm{~mm}$ ID (1.0 $\left.\mathrm{cm}^{2}\right) \times$ maximum working hight in $15 \mathrm{~mm}$. As Fig. 1 also shows, the bottom of the sample holder can be covered by two types of disk stopper : disk 1 is without orifice : and the disk 2 is with a smal! orifice (1 mm ID X $30 \mathrm{~mm}$ length). The stopper disk 2 was

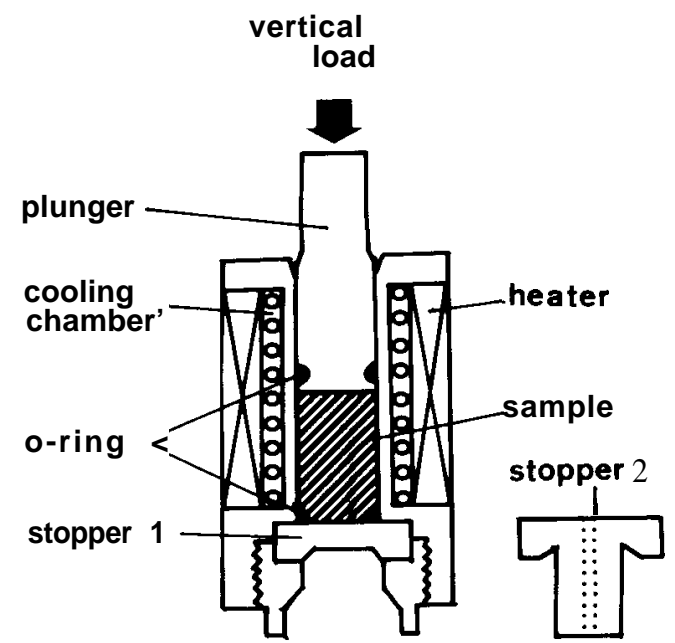

Fig. 1. Cross-sectional view of Flow Tester Cell. Cell size ; $11.3 \mathrm{~mm} \boldsymbol{\phi} \mathbf{x} 43 \mathrm{~mm}$ hight (working hight $15 \mathrm{~mm}$ ). Stopper 1 ; for sample preparation without shearing force. Stopper 2 ; for sample preparation with shearing force. 
used in the heat treatment with shear force. Prior to the heat treatment, the wheat gluten sample was molded into a cylindrical shape by a hand press. By using the stopper disk 1, the molded sample piece was placed into the sample holder of the Cell which was preheated to a desired temperature and kept it for 2 minutes. The temperature of sample piece uniformly reaches the preheated Cell temperature after about 2 minutes. The stress pressure (vertical load by a weighted plunger) was loaded on the top of the sample piece for desired time period. After desired time duration, the Cell was rapidly cooled by cooling water. The treated and cooled sample piece was taken out from the sample holder of the Cell. By similar procedures, sample pieces without shear force were prepared at combinations of temperature ranging from room temperature to $200^{\circ} \mathrm{C}$, and stress pressure ranging from 0 to $250 \mathrm{Kg} / \mathrm{cm}^{2}$. The heat treated sample with shear force was prepared using the stopper disk 2 by blowing it out through the orifice after the heat treatment. During the bolwing, shear force is applied on the heat treated sample. All treated samples were completely ground to 42 mesh undersize by using a grinder.

\section{Sovent used}

Five different kinds of solvents were used for the purpose of solubility analysis of the heat treated and ground wheat gluten; i. e., 1/10 $\mathrm{M}$ acetic acid (AA), mixture of $1 / 10 \mathrm{M}$ acetic acid containing $3 \mathrm{M}$ urea and $1 / 100 \mathrm{M}$ cetyltrimethylammonium bromide (AUC), $1 / 15 \mathrm{M} \mathrm{pH} 6.8$ phosphate buffer, $1 / 15 \mathrm{M} \mathrm{pH} 6.8$ phosphate buffer containing $0.5 \%$ SDS and $5 \mathrm{mM} 2$-mercaptoethanol, and distilled water as a reference. The Britton-Robinson buffer ( $\mathrm{pH} 2$ to 11) was also used to study the effect of $\mathrm{pH}$ on solubility. Reagent grade chemicals (Ishizu Phamaceutical Co. Ltd.) were used for all of above solvents.

\section{Solubility analysis}

One hundred mgs each of the treated sample powder and $15 \mathrm{ml}$ of each solvent were put in $30 \mathrm{ml}$ test tube equipped with screw cap. The test tube was capped tightly, and was slowly rotated in a water bath at $30^{\circ} \mathrm{C}$ for $15 \mathrm{hrs}$ and then centrifuged at 26, $600 \times \mathrm{G}$ for 30 minutes. Subsequently the supernatent was filtered with Toyo No. 5C filter paper. Dissolved protein-in the filtrate was analyzed by absorbance at $280 \mathrm{~nm}$ and/or modified Lowry method (Ross and Schatz, 1973). Solubility of the treated sample was defined as the percentage of the soluble protein to the total protein of the sample.

\section{RESULTS AND DISCUSSION}

\section{Effects of heating temperature and shear force}

Fig. 2 shows the solubility profile of wheat gluten with different solvents at the treatment temperature ranging from room temperature to $200^{\circ} \mathrm{C}$, under the constant stress pressure at $250 \mathrm{Kg} / \mathrm{cm}^{2}$ and with (Fig. 2-A) or without the shear force (Fig. 2B). Within the tested temperature range, the highest and the lowest solubilities of the heat treated gluten were given by phosphate buffer containing SDS and ME, for distilled water or phosphate buffer, respectively. For all sovents except distilled water and phosphate buffer, it is observed that the lowest solubility is obtained by the 


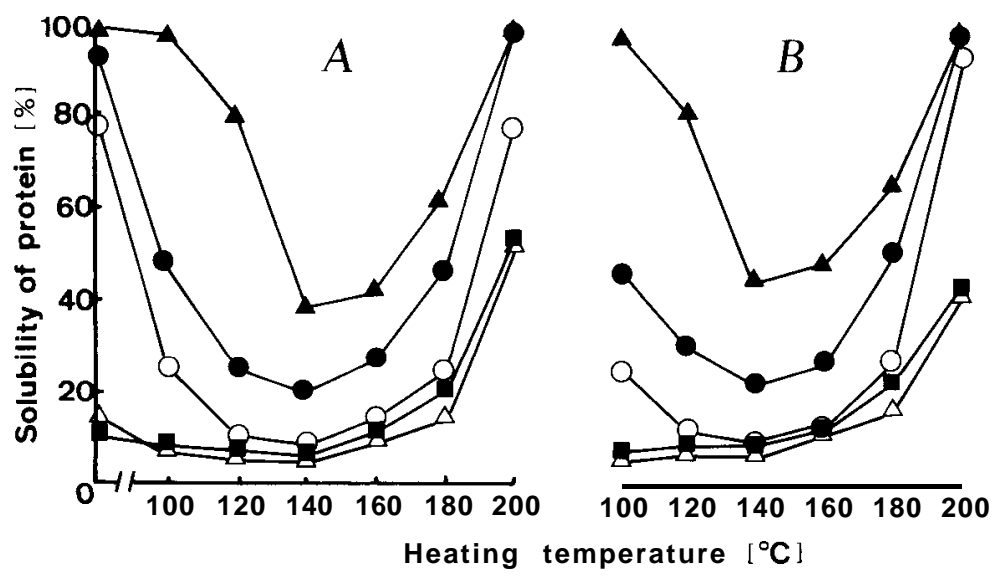

Fig. 2. Solubility profiles of wheat gluten with various solvents at treated temperature ranging $100^{\circ} \mathrm{C}$ to $200^{\circ} \mathrm{C}$ for 5 minutes, under the stress pressure $250 \mathrm{Kg} / \mathrm{cm}^{2}$. A, without shear force ; B, with shear force ; $\bigcirc, 0.1 \mathrm{M}$ acetic acid ; $\mathrm{AUC} ; \triangle, \mathrm{M} / 15$ phosphate buffer $(\mathrm{pH} 6.8) ; \mathbf{\Lambda}, \mathrm{M} / 15$ phosphate buffer containing $0.5 \%$ SDS and $5 \mathrm{mM}$ 2-ME; $\mathbf{\square}$,distilled water.

treatment temperature at $140^{\circ} \mathrm{C}$. The solubility significantly increases with increasing or decreasing temperature apart from $140^{\circ} \mathrm{C}$. These phenomena were in good agreement with the results obtained by Saio et al. (1975) from the heat induced gel of soybean $7 \mathrm{~S}$ and $11 \mathrm{~S}$ protein.

For both of distilled water and phosphate buffer, solubility of the heat treated gluten only slightly decreased up to $140^{\circ} \mathrm{C}$. However, the solubility markedly increased with increasing temperature from $140^{\circ} \mathrm{C}$, and reaching $54 \%$ at $200^{\circ} \mathrm{C}$. The $54 \%$ solubility corresponds to more than 5 folds increase compared with the solubility of native gluten. These results revealed that the water soluble portion of wheat gluten markedly increased at the heat treating temperature above $140^{\circ} \mathrm{C}$.

Fig. 2-B shows the solubility profiles of gluten samples with various solvents. Samples were heat treated at various temperatures and stress forces and then blow out through the orifice in order to impart desirable shear force on the treated gluten. Comparing the solubility profiles in Fig. 2-B with the solubility profiles in Fig. 2-A, it is obvious that there is no significant difference between them. Based on these observations, it can be said that the shear force does not have any significant effect on solubility of heat treated gluten.

Effect of stress pressure on solubility

Fig. 3 shows the solubility profiles of gluten treated at $120^{\circ} \mathrm{C}$ with various solvents. As it is shown in Fig. 3, gluten solubility in all solvents indicated no significant change with differing stress pressure up to $250 \mathrm{Kg} / \mathrm{cm}^{2}$, except in the case of phosphate buffer containing SDS and ME. Fig. 3 shows the result of only heat treatment temperature at $120^{\circ} \mathrm{C}$. However, results with other temperature levels roughly agreed with the results in Fig. 3. Within the range of stress pressure in these experiments, it can be 


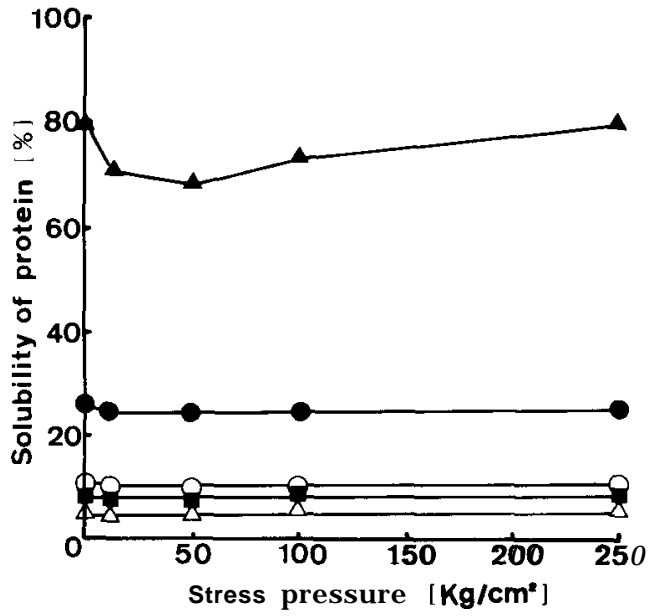

Fig. 3. Effect of stress pressure on soiubility with various solvents of wheat gluten treated at $\mathbf{1 2 0}^{\circ} \mathrm{C}$ for 5 minutes, the symbols are identical to that of Fig. 2.

concluded that the stress pressure does not affect the solubility of heat treated gluten.

\section{Effect of heating time}

Fig. 4 shows the effect of heating time on gluten solubility for $0.1 \mathrm{M}$ acetic acid. The gluten solubility treated at $120^{\circ} \mathrm{C}$ slightly decreased with the increasing heating time until it reached 60 minutes. However, the solubility gradually increased for the sample treated at $140^{\circ} \mathrm{C}$ for the same duration of time. The solubility increased rapidly with the increasing heating temperature above $140^{\circ} \mathrm{C}$, and at $200^{\circ} \mathrm{C}$, the treated gluten almost completely dissolved after 10 minutes heating time. Pence et al. (1953) have

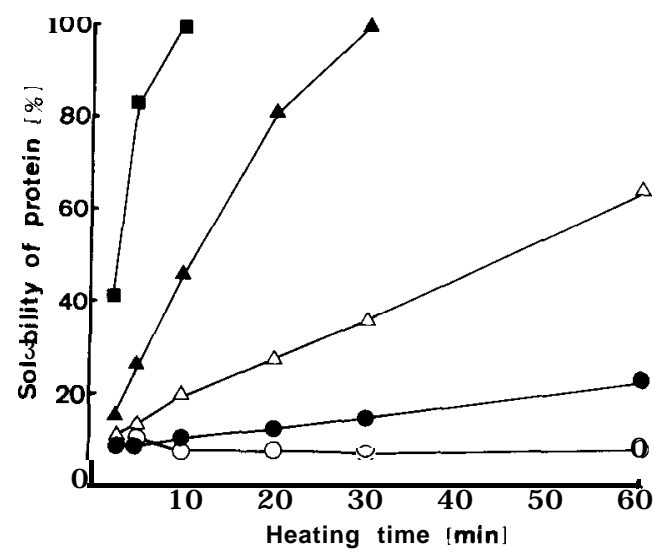

Fig. 4. Effect of heating time on solubility for $0.1 \mathrm{M}$ acetic acid of gluten treated at different temperature under stress pressure $250 \mathrm{Kg} / \mathrm{cm}^{2} .0,120^{\circ} \mathrm{C} ; 0,140^{\circ} \mathrm{C} ; \triangle$, $160^{\circ} \mathrm{C} ; \boldsymbol{\Delta}, 180^{\circ} \mathrm{C} ; \quad \mathbf{\square}, 200^{\circ} \mathrm{C}$. 
reported their study on the effect of heating time and temperature on the solubility of wheat gluten, with heating temperature ranging from 70 to $90^{\circ} \mathrm{C}$. The report stated that the solubilty of gluten rapidly decreased with the increasing temperature up to $90^{\circ} \mathrm{C}$ for the same heating time. Comparing the results of this study with the reported results, it can be concluded that the heat treated gluten can be dissolved when it is treated at the temperature above $120^{\circ} \mathrm{C}$. This phenomenon on gluten solubility may be caused by greater degradation of protein.

\section{E ffect of moisture contents}

Fig. 5 shows the effect of initial moisture content of gluten on the solubility. The parameters in Fig. 5 are initial moisture content of gluten ranging from $11 \%$ to $49 \%$, heat treatment temperature at $140^{\circ} \mathrm{C}$ and $180^{\circ} \mathrm{C}$ for 5 minutes, and constant stress pressure at $250 \mathrm{Kg} / \mathrm{cm}^{2}$. The heat treated gluten was dissolved in $0.1 \mathrm{M}$ acetic acid or in 1/15 M phosphate buffer containing SDS and ME. In both solvents, it can be said that the moisture content does not affect the solubility of heat treated gluten at $140^{\circ} \mathrm{C}$. On the other hand, the solubility of heat treated gluten at $180^{\circ} \mathrm{C}$ was considerably higher at a higher moisture content. Based on the finding from Fig. 5, it is considered that the initial moisture content of gluten affects the solubility, when the heat treatment temperature is higher than $140^{\circ} \mathrm{C}$.

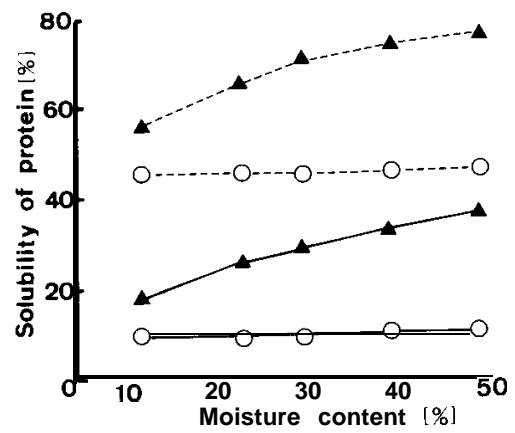

Fig. 5. Effect of initial moisture content of gluten treated at various temperature for $5 \mathrm{~min}$ under stress pressure $250 \mathrm{Kg} / \mathrm{cm}^{2} . \cdots, \mathrm{M} / 15$ phosphate buffer containing 0 . $5 \%$ SDS and $5 \mathrm{mM} 2-\mathrm{ME} ;-, 0.1 \%$ acetic acid $; \bigcirc, 140^{\circ} \mathrm{C} ; \boldsymbol{\Delta}, 180^{\circ} \mathrm{C}$.

\section{Effect of solvent pH}

Fig. 6 shows the effect of the $\mathrm{pH}$ of solvent (Britton-Robinson buffer) on solubility of the heat treated gluten. The pH-solubility profiles of the gluten indicated the maximum solubility at $\mathrm{pH} 2$ and 11 . The minimum solubility depended on the heat treatment condition as it is shown in Fig. 6. The minimum solubility was $50 \%$ at $\mathrm{pH}$ 4.0 for heat treatment at $200^{\circ} \mathrm{C}$ for 5 minutes, while minimum solubility at the room temperature for 5 minutes was $15 \%$ for a broad $\mathrm{pH}$ range 5 to 6 . The $\mathrm{pH}$ value that gave the minimum solubility corresponds to the isoelectric point of gluten. It also agreed with the $\mathrm{pH}$ value of 5 to 9 at the minimum solubility of gluten in water, reported by Kasarda et al. (1976) and Sarkki (1980). As it is clear from Fig. 6, the 


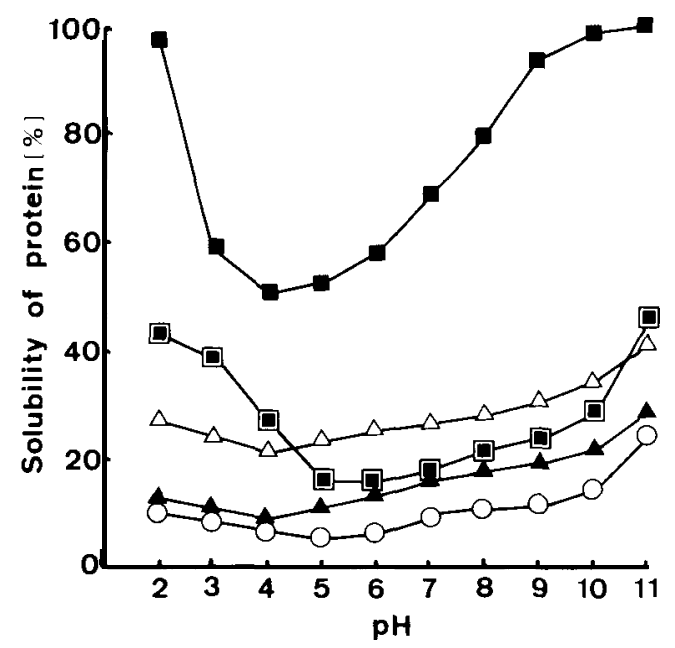

Fig. 6. Effect of solvent $\mathrm{pH}$ on solubility of heat-treated gluten. Other experimental conditions are the same as in Fig. 5. $\square$, native gluten $; \bigcirc, 120^{\circ} \mathrm{C} ; \boldsymbol{\Delta}, 160^{\circ} \mathrm{C} ; \Delta$, $180^{\circ} \mathrm{C} ; \mathbf{\square}, 200^{\circ} \mathrm{C}$.

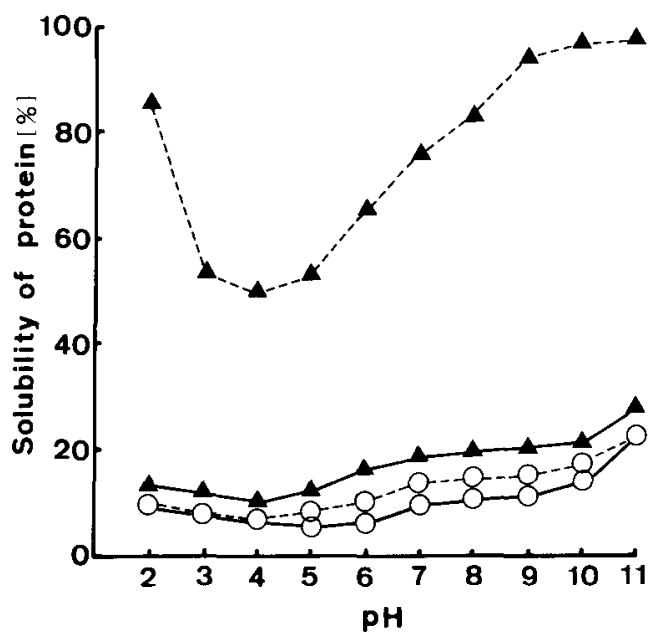

Fig. 7. Effect of heating time on $\mathrm{pH}$-solubility profiles of heat-treated gluten under stress pressure $250 \mathrm{Kg} / \mathrm{cm}^{2}$. $-5 \mathrm{~min} ; \cdots+., 60 \mathrm{~min} ; \mathrm{O}, 120^{\circ} \mathrm{C} ; \mathrm{A}, 160^{\circ} \mathrm{C}$.

gluten treated under the temperature at 120 to $180^{\circ} \mathrm{C}$ showed only a small difference between maximum and minimum solubility in comparison with gluten treated at room temperature (correspond to native gluten). The difference in solubilities between the heat treated gluten at the temperature from 120 to $180^{\circ} \mathrm{C}$ and the native gluten became greater at the acidic region than at the alkaline region. It should be noted that the heat treated gluten at $200^{\circ} \mathrm{C}$ showed significantly higher solubility through out the $\mathrm{pH}$ range 2 to 11 compared with others. Comparing with the $\mathrm{pH}$ value that gave the minimum 
solubility for native gluten, $\mathrm{pH}$ values that gave the minimum solubility for the heat treated gluten was shifted almost $1 \mathrm{pH}$ unit toward the acidic side.

Fig. 7 shows the effect of heating time on pH-solubility profiles of gluten. Comparing these two cases with heating time 5 and 60 minutes, no significant dependency of solubility on the $\mathrm{pH}$ of gluten treated at $120^{\circ} \mathrm{C}$ can be recognized. In the case with the temperature at $160^{\circ} \mathrm{C}$ for 60 minutes, however, the solubility profile is similar to that of the gluten treated at $200^{\circ} \mathrm{C}$ for 5 minutes in Fig. 6. From these results, it can be said that the heating time gives similar effect as the heating temperature on the solubility of heat treated gluten.

\section{CONCLUSIONS}

As a basic study of texturization characteristics of protein by extrusion processing, we carried out the study on thermal characteristics of wheat gluten under the existence of stress pressure. From the experimental data on the solubility expressed as indices with different solvents, following conclusion can be drawn. The solubility of wheat gluten treated at a high temperature is dependent primarily on treatment temperature, heating time, kind of solvent and $\mathrm{pH}$ of the solvent. The shear force and the size of stress pressure have almost no effect.

\section{REFERENCES}

Kasarda, D. D., J. E. Bernardin and C. C. Nimmo 1976 Wheat proteins In "Advances in Cereal Science and Technology", ed. by Y. Pomeranz, AACC, St. Paul, MN, pp. 158-236

Ross, E. and G. Schatz 1973 Assay of protein in the presence of high concentrations of sulfhydryl compounds. Anal. Biochem., $54:$ 304-306

Saio, K., Sato, I. and T. Watanabe 1974 Food use of soybean 7S and 11S protein : High temperature expansion characteristics of gels. J. Food Sci., 39: 777-780

Saio, K., Terashima, M. and T. Watanabe 1975 Food use of soybean $7 \mathrm{~S}$ and $11 \mathrm{~S}$ protein: Heat denaturation of soybean proteins at high temperature. J. Food Sci., $40: 537-540$

Sarkki, M. L. 1980 Cereal for food and beverages. In "Recent Progress in Cereal Chemistry", ed. by G. E. Ignlett and L. Munck, Academic Press, New York, pp. 155-185

Sheard, P.R., A. Fellows, D.A. Ledward and J. R. Mitchell 1986 Macromolecular changes associated with the heat treatment of soya isolate. J. Food Technol., 21: 55-60 